Original Research Paper

\title{
Edukasi Masyarakat Untuk Pengelolaan Sampah Di Desa Kumbang Kecamatan Masbagik Lombok Timur
}

\author{
Ahmad Jupri $^{1}$, Athifah ${ }^{2}$, Hety Adelya Elys ${ }^{3}$, Baiq Lika Asmarinda ${ }^{4}$, Naufal Atsauri ${ }^{5}$ \\ 1) Program Studi Ilmu Lingkungan FMIPA, Universitas Mataram, Maratam, Indonesia \\ 2) Program Studi Biolog FMIPA Universitas Mataram, Maratam, Indonesia \\ 3) Program Studi Sekolah Dasar, FKIP Universitas Mataram, Mataram Indonesia \\ 4) Program Studi Matematika, FKIP Universitas Mataram, Mataram Indonesia \\ 5) Program Studi Tehnik Elekto, Fak Teknik Universitas Mataram, Mataram Indonesia
}

DOI: https://doi.org/10.29303/jpmpi.v3i2.521

Sitasi:. Jupri. A., Athifah., Elys, H. A., Asmarinda, B. L., \& Atsauri, N. (2020). Edukasi Masyarakat Untuk Pengelolaan Sampah Di Desa Kumbang Kecamatan Masbagik Lombok Timur. Jurnal Pengabdian Magister Pendidikan IPA, 3(2)

Article history

Received: 15 Oktober

Revised: 18 Nopember

Accepted: 30 Nopember

*Corresponding Author:

Ahmad Jupri, Program Studi

Ilmu Lingkungan FMIPA

Universitas Mataram, Mataram, Indonesia.

Email: juprizikril@gmail.com

\begin{abstract}
Desa Kumbang Kecamatan Masbagik Kabupaten Lombok Timur merupakan salah satu desa yang juga memiliki masalah terkait pengelolaan sampah baik itu berupa sampah rumah tangga ataupun sampah industri. Alternatif solusi yang dapat dilakukan untuk mengatasi permasalahan tersebut adalah dengan memberikan edukasi pada masyarakat tentang cara pengelolaan beraneka macam sampah lingkungan. Tujuan dari program ini adalah untuk untuk meningkatkan mutu dan kualitas desa dengan cara memberikan dan menambah ilmu pengetahuan masyarakat Desa Kumbang dalam pengelolaan sampah untuk menjadi barang yang lebih berguna dan menambah income atau pemasukan ekonomi. Program ini menggunakan metode kualitatif dengan pendekatan kualitatif deskriptif. Sedangkan untuk pengolahan data dianalisis dengan cara penyajian data dan penarikan kesimpulan atau verifikasi. Hasil dari program pemberdayaan masyarakat ini adalah terbentuknya masyarakat berkualitas yang mampu mengelola sampah menjadi barang yang bernilai ekonomi dan sadar akan pentingnya menjaga kebersihan lingkungan.
\end{abstract}

Keywords: Edukasi; Pengelolaan sampah; income; Desa Kumbang.

\section{Pendahuluan}

Pesatnya perkembangan ekonomi, industri dan sosial di Indonesia menimbulkan banyak hal kontraproduktif artinya secara ekonomi bersifat positif tetapi dilain pihak akan memberikan dampak buruk pada lingkungan. Diantara sisi negatif yang terdampak adalah turunnya kualitas lingkungan hidup seperti pencemaran lingkungan yang diakibatkan karena limbah industri ataupun sampah rumah tangga. Berdasarkan data dari Bank Dunia (2012) menyatakan bahwa sampah yang dihasilkan oleh kota-kota di Indonesia mencapai 152.921 ton perhari.

Pengelolaan sampah di Indonesia selama ini biasanya dilakukan dengan cara dikumpulkan dan ditampung pada satu tempat pembuangan akhir (TPA). Namun pengelolaan sampah dengan metode dibatasi oleh keterbatasan lahan dan dana yang besar (Alfan, 2017). Hal ini juga yang menjadi masalah di Desa Kumbang Masbagik, dimana tidak tersedianya tempat pembuangan sampah dan jauhnya jarak dari TPA sehingga sebagian besar masyarakat membuang sampahnya sembarangan di 
sungai atau menimbunnya di pekarangan kemudian dibakar.

Terdapat dua kategori sampah di Desa Kumbang Kecamatan Masbagik yakni sampah rumah tangga dan limbah dari industri gergaji kayu berupa serbuk gergaji dan sawmel. Limbah serbuk gergaji di Desa Kumbang dihasilkan hampir setiap hari, dimana hal ini menimbulkan masalah dalam penanganannya. Padahal berdasarkan Kurniaty dan Rizal (2011) limbah serbuk gergaji yang dihasilkan dari limbah industri kayu dapat dimanfaatkan untuk berbagai keperluan seperti pembuatan briket batu bara dan batako serbuk kayu. Selain itu berdasarkan penelitian Hariadi, dkk (2013) serbuk gergaji merupakan substrat umum dan pokok dalam usaha bidaya jamur tiram.

Berdasarkan hal tersebut untuk menanggulangi berbagai masalah yang disebabkan oleh sampah baik dari jenis sampah anorganik dan organik di Desa Kumbang kami memberikan solusi berupa edukasi pada masyarakat tentang pengelolaan sampah menjadi barang yang berguna.

\section{Metode}

\section{1) Waktu dan Tempat}

Program ini dilakukan di Desa Kumbang Kecamatan Masbagik Kabupaten Lombok Timur Nusa Tenggara Barat pada bulan Januari s/d Maret 2019.

\section{2) Alat dan Bahan}

Bahan yang dibutuhkan dalam program ini berupa sampah anorganik, sampah limbah industri kayu (somel), bibit tanaman, dedak, kapur, air dan bibit jamur. Alat yang digunakan dalam program ini adalah set alat kebersihan, kawat, cat tembok dan set plastik baglog.

\section{3) Bentuk Kegiatan}

Bentuk kegiatan dalam program edukasi pengelolaan sampah lingkungan Desa Kumbang adalah 1) Persiapan alat dan bahan untuk program taman baca berbasis ecobrick, 2) Memasukkan sampah plastik kedalam botol plastik dan menghias botol plastik, 3) Menanam bibit bunga pada pot ecobrick, 4) Membuat taman baca dan menyiapkan lokasi budidaya jamur, 5) Persiapan alat dan bahan budidaya jamur, 6) Sosialisasi pembuatan baglog jamur, 7) Mengemas produk budidaya jamur, 7) Melakukan kegiatan bersih-bersih yamg dirangkai dalam kegiatan "Jum'at Bersih" dan 8) Monitoring dan evaluasi.
4) Metode

Program ini menggunakan metode kualitatif dengan pendekatan kualitatif deskriptif karena mampu menyajikan gambaran secara detail tentang suatu situasi, selanjutnya pendekatan kualitatif itu umumnya merupakan data yang dikumpulkan berupa kata-kata, gambar dan bukan angka. Pengambilan data pada program ini dilakukan dengan tehnik observasi lapangan, wawancara dan studi pustaka yang selanjutnya dianalisis dengan melakukan penarikan kesimpulan.

\section{Hasil dan Pembahasan}

Program edukasi masyarakat dalam pengelolaan sampah di Desa Kumbang Kecamatan Masbagik Kabupaten Lombok Timur dalam rangka pemberdayaan masyarakat desa dilakukan secara terstruktur dan melibatkan masyarakat secara langsung seperti Karang Taruna, IPMAKU (Ikatan Pemuda Mahasiswa/i Kumbung), HPMD (Himpunan Pemuda Mahasiswa/I Bangket Daya), warga desa Kumbung secara umum. Program edukasi masyarakat tentang pengelolaan sampah ini merangkum tiga kegiatan yang berbeda dan bertujuan sekaligus untuk membantu penanganan masalah sampah yang terjadi di Desa Kumbang.

\section{1) Taman Baca Berbasis Ecobrick}

Program edukasi pengelolaan sampah dimulai dengan pengolahan sampah anorganik menjadi bahan yang berguna, kami menawarkan konsep ecobrick. Ecobrik merupakan teknik pengelolaan sampah plastik yang terbuat dari botolbotol plastik bekas yang didalamnya telah diisi berbagai sampah plastik hingga padat yang nantinya dapat dibuat menjadi kursi, meja, pot bunga atau bahkan bata bangunan rumah (Russel and Irene, 2014). Selain bertujuan untuk menanggulangi permasalahan sampah, program ini juga bertujuan untuk meningkatkan minat baca serta sumber edukasi untuk masyarakat Desa Kumbang. Pada program ini bahan utama yang dibutuhkan adalah sampah anorganik dari jenis plastik dan semua jenis sampah yang sukar terurai dan juga bibit tanaman. 


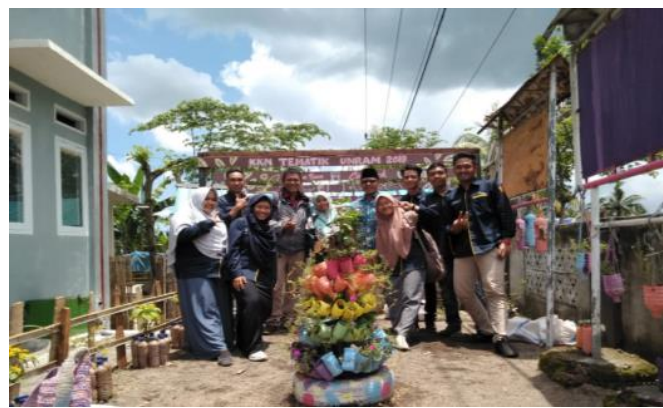

Gambar 1. Opening Taman Baca Berbasis Ecobrick Oleh Bapak M.Taufik (Kades Desa Kumbang)

Setelah program ini berjalan dan dihasilkan taman baca berbasis ecobrick, warga masyarakat setempat dapat mengambil banyak manfaat tertamanya untuk kalangan anak sekolah dasar, mereka mampu memahami konsep 3R (Recycle, Reduce dan Reuse) ketika belajar sambil bermain di taman baca ini. Sedangkan untuk kalangan remaja dan orang tua taman baca berbasis ecobrick ini merupakan tempat menambah ilmu pengetahuan baru, juga sebagai lokasi untuk dapat melakukan foto selfie yang juga merupakan tempat berkumpul yang didukung oleh hotspot wifi desa. Selain itu karena lokasinya berdekatan dengan kantor desa Kumbang, maka taman baca berbasis ecobrick ini dapat dijadikan taman percontohan. Bahwa dari sampah yang diolah dapat menjadi suatu yang cantik dan bermanfaat untuk banyak orang.

2) Budidaya Jamur Tiram

Program budidaya jamur tiram di Desa Kumbang merupakan program lanjutan dari KKN Unram 2018 yang dibimbing langsung oleh bapak Dr. H. Ahmad Jupri, M.Eng., oleh karena itu pada program ini difokuskan pada cara pengolahan produk dari budidaya jamur tiram juga tehnik pemasaran serta pengemasan dari produk jamur tiram tersebut. Oleh karena itu dalam program ini kami melakukan sosialisasi terkait Upaya pembibitan jamur tiram dan usaha berkelanjutan budidaya jamur yang bermitra dengan Sekolah Budidaya Jamur OJK Nusa Tenggara Barat.

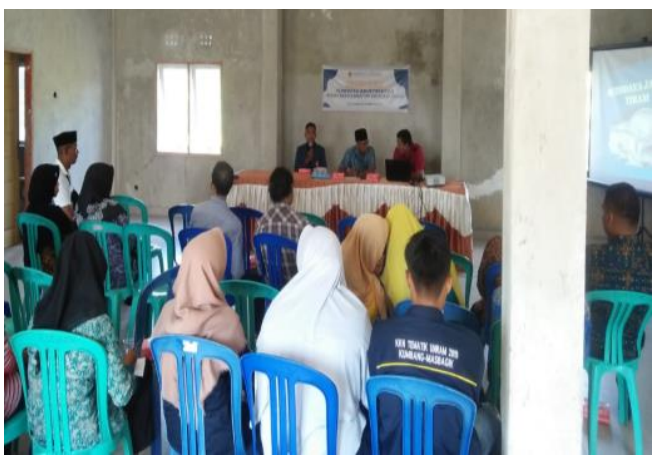

Gambar 2. Sosialisasi Pembibitan Jamur Tiram dan Usaha Berkelanjutan Budidaya Jamur Tiram

Melalui program ini dilaksanakan pelatihan pengolahan limbah kayu (serbuk gergaji) sebagai bahan pembuatan media jamur yang dikenal dengan istilah baglog. Hasil yang diperoleh dengan diadakannya program ini yaitu banyak sekali masyarakat setempat yang tertarik untuk mengolah limbah potensial berupa serbuk gergaji halus untuk diolah menjadi media tanam jamur serta bisa dijadikan sebagai solusi penambah lowongan kerja. Kepala desa setempat juga sepakat untuk menjadikan budidaya jamur sebagai salah satu program upaya memajukan ekonomi masyarakat dengan memberikan dana gratis bagi pemuda desa yang ingin mempelajari pembudidayaan jamur di Sekolah Budidaya Jamur OJK NTB, mengingat akan melimpahnya bahan baku untuk budidaya jamur di Desa Kumbang.

Program budidaya jamur yang telah dilaksanakan di Desa Kumbang termasuk berhasil, karena kondisi lingkungan seperti suhu dan cuaca di desa ini yang sangat cocok untuk pertumbuhan jamur. Berdasarkan Widyastuti dan Donowati (2008) menyatakan bahwa suhu udara yang lembab serta cahaya matahari cukup mampu mengoptimalkan tumbuhnya badan buah pada jamur. Hasil panen pertama kali budidaya jamur yang bagus, besar dan berat menunjukkan bahwa iklim Desa Kumbang yang dingin dan lembab menjanjikan keberhasilan budidaya jamur di desa ini. 


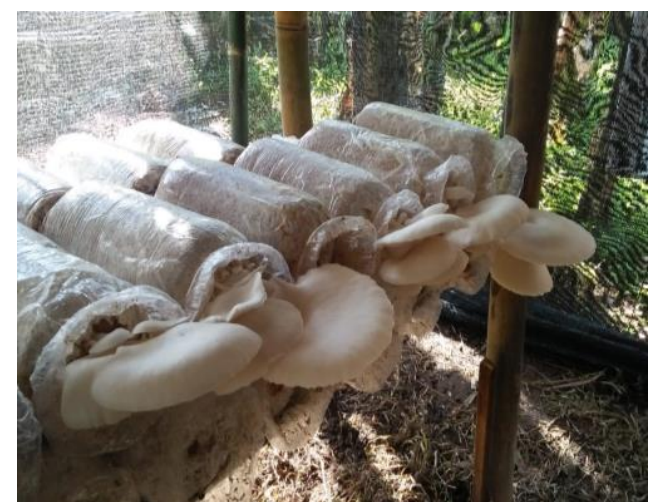

Gambar 3. Panen pertama Budidaya Jamur Tiram Kumbang

Selain itu pada program ini, dilakukan edukasi wirausaha terkait olahan jamur tiram menjadi snack konsumsi yag bergizi. Menurut Thormy (2004) dalam Donowati (2008) jamur merupakan sumber pangan yang nilai gizinya setara dengan daging dan ikan, dimana kandungan asam amino jamur tiram (46 gram/100 gram) hampir sepadan dengan telur ayam (47,1 gram/ 100 gram). Maka pada program ini kami membuat olahan kripik jamur tiram dengan harapan dapat membantu perekonomian dan meningkatkan nilai gizi makanan untuk warga setempat.

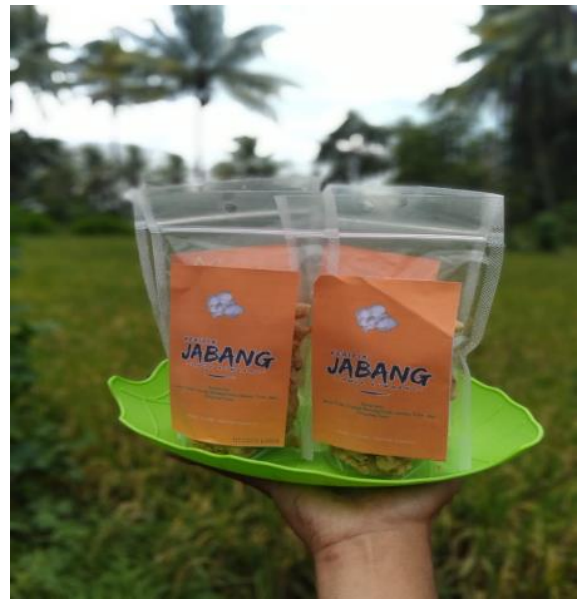

Gambar 4. Produk Kripik JABANG (Jamur Tiram Kumbang)

\section{3) Jum'at Bersih}

Program ketiga yakni upaya membantu masalah sampah yang berserakan di lingkungan Desa Kumbang, yakni melakukan gerakan "Jum'at Bersih" bertujuan untuk menggerakkan semangat masyarakat setempat untuk tetap menjaga kebersihan lingkungan dan meningkatkan kesadaran masyarakat untuk membuang sampah pada tempatnya. Program ini dilakukan tiap minggu dengan berkeliling setiap dusun di Desa Kumbang mencakup 4 dusun sekaligus yakni dusun Kumbung Timur, Kumbung Barat, Bangket Daya dan Sangiang. Program ini terus mengaitkan dan mengajak masyarakat seluruh masyarakat dari kalangan orang dewasa, remaja sampai dengan anak-anak.

Hal ini berguna untuk menanamkan karakter cinta lingkungan dan agar generasi muda juga dapat mewariskan nilai peduli lingkungan terhadap anak-anak. Sebagaimana yang program yang dijalankan di Kampung Margorukun Surabaya berupa kampong hijau dimana orangtua dalam keluarga selalu mengajarkan dan mengajak serta anak-anak untuk mengikuti kerja bakti rutin guna membentuk karakter peduli lingkungan pada anak (Prasetiyo dan Totok, 2013). Hasil dari program ini didapatkan bahwa adanya semangat yang tinggi dari masyarakat setempat untuk melakukan gotong royong upaya pembersihan lingkup dusun. Selain itu juga adanya antusiasme dan partisipasi warga dengan membantu kami memberikan alat-alat kebersihan dan usaha untuk membuang sampah pada tempatnya.

\section{Kesimpulan}

Berdasarkan hasil yang didapatkan setelah melakukan serangkaian program edukasi masyarakat tentang pengelolaan sampah lingkungan di Desa Kumbang Kecamatan Masbagik Lombok Timur dapat disimpulkan bahwa masyarakat Desa Kumbang memiliki keinginan untuk meningkatkan kualitas desa dengan cara tetap berpartisipasi untuk menjaga kebersihan lingkungan dan semangat dalam menambah ilmu terkait pengelolaan sampah untuk menjadi barang yang lebih berguna dan menghasilkan pemasukan ekonomi. Selain itu bentuk partisipasi yang juga dilakukan oleh masyarakat Kumbang adalah tetap mengikuti kerja bakti rutin (Jum'at Bersih), melakukan pemilahan sampah, penataan taman baca, mengikuti sosialisasi budidaya jamur dan pengelolaan usaha budidaya jamur dan menyumbangkan alat-alat kebersihan.

\section{Ucapan Terima Kasih}

Terima kasih kepada Universitas Mataram yang telah mendukung secara moral maupun material, dan pihak-pihak terkait yang senantiasa 
selalu memberikan dukungan dalam terlaksananya kegiatan pengabdian kepada masyarakat ini.

\section{Daftar Pustaka}

Alfan, M. 2017. Dampak Tempat Pembuangn Akhir (TPA) Sampah Kebon Kongok Terhadap GangguanKesehatan Masyarakat Desa Suka Makmur Kecamatan Gerung Kabupaten Lombok Barat. Skripsi : UIN Mataram.

Danim, Sudarman. 2002. Menjadi Peneliti Kualitatif. CV. Pustaka Setia : Bandung.

Donowati, Tjokrokusumo. 2008. Jamur Tiram (Pleoretus ostreatus) untuk Meningkatkan Ketahanan Pangan dan Rehabilitasi Lingkungan. Jurnal Rekayasa Lingkungan. 4(1) : 53-62.

Hariadi, N., Lilik Setyobudi dan Ellis Nihayati. 2013. Studi Pertumbuhan dan Hasil Produksi Jamur Tiram (Pleoretus ostreatus) pada Media Tumbuh Jerami Padi dan Serbuk Gergaji. Jurnal Produksi Tanaman. 1(1) : 47-53.

Maier, R., Irene Bakisan. Vision Ecobrick Guide Mobilize Imagination and Collaboration to Clean and Green your Home, School and Community Version 2.1. The Creative Commons Attributions Non-commercials. Diakses online https://www.ecobricks.org/wpcontent/uploads/2014/02/Vision-EcoBrickGuide-2.1.pdf.

Muchtar. 2007. Pemberdayaan Masyarakat Melalui Program Pengembangan Distrik Kajian Kebijakan dan Implementasinya di Provinsi Papua. Jurnal Penelitian dan Pengembangan Kesejahteraan Sosial.12(2) : $1-10$.

Prasetiyo,Wibowo Heru dan Totok Suyanto. 2013. Strategi Pendidikan Karakter Peduli Lingkungan Melalui Program Kampung Hijau di Kampung Margorukun Surabaya. Kajian Moral dan Kewarganegaraan. 2(1) : $302-316$.

Sugiyono. 2018. Metode Penelitian Kuantitatif, Kualitatif, dan R\&D. Alfabeta : Bandung.

The World Bank.2012. What a Waste a Global Review of Solid Waste Management. Urban Development and Local Government: Washington, DC USA.
Kurniaty, D.R., dan Mohammad Rizal. 2011. Pemanfaatan Hasil Pengelolaan Sampah Sebagai Alternatif Bahan Bangunan Kontruksi. Jurnal SMARTek. 9 (1) : 47-60.

Widyastuti, Netty dan Donowati Tjokrokusumo. 2008. Aspek Lingkungan sebagai Faktor Penentu Keberhasilan Budidaya Jamur (Pleurotus sp.). Jurnal Teknologi Lingkungan. 9(3) : 287-293. 